\title{
A Japanese Encephalitis Virus NS3 Inhibitor Produced by a Streptomyces sp.
}

\author{
Masahiro Hatsu*, Masahiro Tanaka, Andi Utama, Hiroyuki Shimizu1, \\ and Kazuhiro Takamizawa
}

\author{
Department of Bioprocessing, Faculty of Agriculture, Gifu University, 1-1 Yanagido, Gifu 501-1193, Japan \\ and ${ }^{1}$ Department of Virology II, National Institute of Infectious Diseases, Gakuen 4-7-1, \\ Musashimurayasa-shi, Tokyo 208-0011, Japan
}

(Received Jan. 8, 2002 / Accepted May 7, 2002)

Japanese encephalitis virus (JEV) is an arthropod-borne flavivirus that causes central nervous diseases such as meningitis and severe encephalitis ${ }^{1}$. JEV belongs to the genus Flavivirus of the family Flaviviridae and has a positive, single-strand RNA genome (about $11 \mathrm{~kb}$ ) that is translated into a single polyprotein precursor, Flavivirus NS3. This protein is a multifunctional protein that possesses several enzymatic activities. Knowledge on the function of the genome and its encoded viral proteins is essential in determining the validity of these targets for anti-virus drug discovery and development. Like other cellular processes such as DNA replication and mRNA transcription and translation, viral replication typically requires a separation of duplex nucleic acids. This reaction is mediated by a class of RNA/DNA unwinding enzyme, called helicase, which uses energy derived from coupled NTP hydrolysis (NTPase). The serine protease activity of the NS3 protein of flaviviruses has been localized in one-fourth of the Nterminal of the protein ${ }^{2-4}$. The rest of the NS3 protein contains sequence motifs that are presumed to be responsible for NTP binding, NTP hydrolysis and RNA helicase activities. The JEV NS3 protein contains GKT/S and DExH motifs which are commonly found in the DExH protein subfamily of the DEAD-box protein family ${ }^{5-7)}$. Recently, we have identified and characterized both NTPase and RNA helicase activities of the recombinant JEV NS3 protein which was expressed in Escherichia coli ${ }^{8,9)}$. Although the flavivirus infection has a substantial medical impact, attempts to develop effective antiviral agents have been limited and unsuccessful. Therefore, we have been searching for natural NTPase (ATPase) inhibitors produced by microorganisms. Here, we report about a protein substance, that inhibits ATPase and RNA helicase activities of JEV, from a Streptomyces sp.

To measure ATPase activity, the amount of free phosphate moiety released from ATP was measured as described previously ${ }^{8,9)}$. Briefly, $50 \mu \mathrm{l} /$ well of reaction mixture containing $10 \mathrm{mM}$ Tris-HCl buffer ( $\mathrm{pH}$ 6.5), 2 $\mathrm{mM}$ ATP, $1 \mathrm{mM} \mathrm{MgCl} 2$, and purified NS3 protein $(0.8$ pmol) produced by E. coli was incubated with or without culture broth $(3 \mu \mathrm{l})$ in a 96 -well microtiter plate at $30^{\circ} \mathrm{C}$ for $30 \mathrm{~min}$. The reaction was stopped by adding $100 \mu \mathrm{l} /$ well of dye solution (water : $0.081 \%$ malachite green : $5.7 \%$ ammonium molybdate in $6 \mathrm{M} \mathrm{HCl}: 2.3 \%$ poly vinyl alcohol $=2: 2: 1: 1, \mathrm{v} / \mathrm{v})$. The absorbance at $620 \mathrm{~nm}$ was measured with a reference absorbance at $492 \mathrm{~nm}$. The inhibition rate $(\%)$ was calculated by using the equation of (A-I)/A x 100, where A is the enzyme activity measured in the absence of the inhibitory substance and I is the activity measured in the presence of the inhibitory substance. Among 2,102 strains screened, the strain THT-1 of which culture broth supernatant showed a clear inhibitory activity was chosen to characterize the inhibitory substance. The strain showed taxonomic characteristics falling into those of Streptomyces (data not shown).

The inhibition of ATPase activity of JEV by the culture broth of the strain THT-1 was measured during its cultivation. When the strain was cultured at $30^{\circ} \mathrm{C}$ with shaking in a medium composed of $1 \%$ galactose, $1 \%$ dextrin, $0.5 \%$ Bacto-soytone, $0.1 \%\left(\mathrm{NH}_{4}\right)_{2} \mathrm{SO}_{4}$, and $0.1 \% \mathrm{CaCO}_{3}$, the inhibition reached its highest level after 3 days incubation. The inhibitory substance was purified from the cultured broth, using active carbon, gel filtration followed by anion exchange chromatography. The culture broth was centrifuged at 3,000 rpm for 20 min to remove cells and insoluble materials. The resulting supernatant was added to a column containing active carbon equilibrated with $\mathrm{H}_{2} \mathrm{O}$, and the inhibitory substance was eluted. Subsequently, the eluate was subjected to Sephadex G-100 (Pharmacia) column chromatography using $20 \mathrm{mM}$ Tris- $\mathrm{HCl}$ buffer $(\mathrm{pH}$ 7.5). The inhibitory fractions were pooled, concentrated and then chromatographed on a DEAE Toyopearl 650M column (Tosoh) with $20 \mathrm{mM}$ Tris- $\mathrm{HCl}$ buffer containing $0-1.0 \mathrm{M} \mathrm{NaCl}$. The active fractions were dialyzed against deionized water and lyophilized.

The final inhibitory fraction produced a single band on native PAGE and 3 bands (67, 60 and $58 \mathrm{kDa}$ ) upon SDSPAGE suggesting that the inhibitory substance might be an aggregate of 3 peptides. The $\mathrm{N}$-terminal amino acid sequence of the $60 \mathrm{kDa}$ band was determined to be EMKLGTLGTVIDK by automated Edman degradation with a pulsed-liquid sequencer Model 491 (Perkin Elmer Applied Biosystem, USA), equipped with a PROCISETM 1.1a data analysis software. A search of sequence databases using BLAST revealed significant similarity between this sequence and 90k-protease ${ }^{10-13)}$ and Bacillopeptidase

* Corresponding author. 
F12-17), a heat shock protein produced by Bacillus subtilis. However, the amount of purified substance obtained was too small to perform additional experiments.

The substance provided an $\mathrm{IC}_{50}$ value of $1.47 \mu \mathrm{g} / \mathrm{ml}$ for the inhibition of ATPase activity of JEV. As shown in Fig. 1 , the inhibition of the ATPase activity of JEV was noncompetitive upon Lineweaver-Burk plot analysis. However, the substance did not inhibit ATPase activity of hepatitis $\mathrm{C}$ virus (HCV). In this regard, a marked difference was found in the sequence of DExH motif of these two enzymes; i.e. DEAH and DECH in JEV and HCV, respectively. The NTPase/helicase domain of the NS3 protein of JEV and HCV is classified into the DExH protein subfamily of helicase superfamily ${ }^{5,18}$. DExH motif is one of the most important sequence motifs presumably involved in NTP hydrolysis. Though the mechanism of inhibition is not elucidated, the substance could be a new tool to investigate the role of NTPase in virus replication.

To measure RNA helicase activity, the assay ${ }^{8,9)}$ using a dsRNA substrate was performed as shown in Fig. 2. Briefly, $20 \mu \mathrm{l}$ of the reaction mixture containing $25 \mathrm{mM}$ MES (pH 6.0), $2 \mathrm{mM}$ DDT, $2 \mathrm{mM} \mathrm{MgCl}_{2}, 5 \mathrm{mM}$ ATP, 1.25 units of RNasin (Promega), $0.32 \mathrm{fmol}$ of the RNA substrate ( ${ }^{32} \mathrm{P}$-labeled RNA fragment synthesized with the Riboprobe System-T7, Promega), and purified NS3 protein was incubated at $37^{\circ} \mathrm{C}$ for $30 \mathrm{~min}$. Then, $5 \mu \mathrm{l}$ of loading buffer was added to terminate the reaction. The sample was analyzed by $10 \%$ native polyacrylamide gel electrophoresis. The BAS 2000 Image Analyzing System (Fuji Photo Film) was used to obtain the autoradiographic pattern and to quantify the labeled RNA. As shown in Fig. 3, purified JEV NS3 protein converted the dsRNA to ssRNA indicating helicase activity (compare lanes S1 and S2). The inhibition was $95 \%$ and almost complete at $0.05 \mu \mathrm{g}$ and $0.1 \mu \mathrm{g} / 20 \mu \mathrm{l}$, respectively. This activity was obviously inhibited when the protein was incubated in the presence of increasing amount of the inhibitory substance (Fig. 3: lanes S4 and S5).

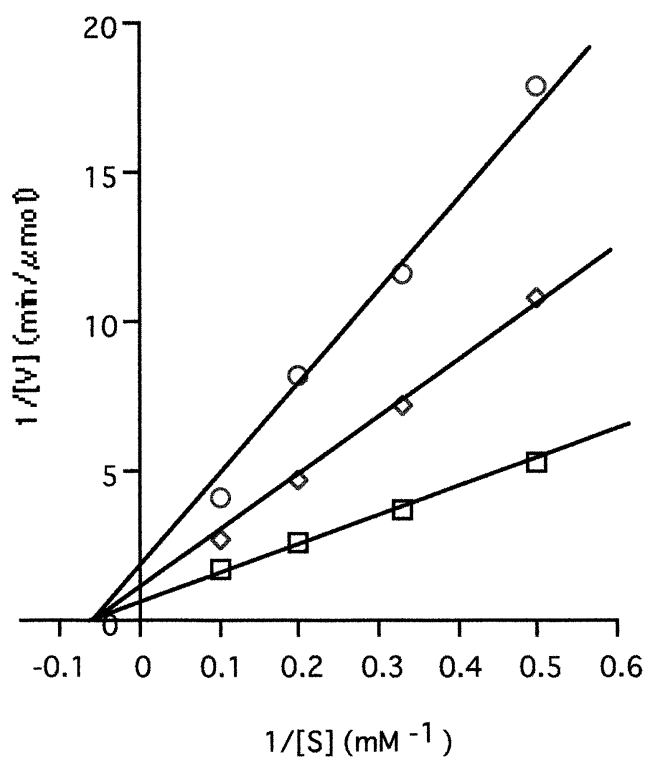

Fig. 1 Lineweaver-Burk Plot of Inhibition against ATPase Activity of JEV.

Concentration of inhibitory substance was $0(\square), 0.5(\diamond), 1.0(\bigcirc)$ $\mu \mathrm{g} / \mathrm{ml}$.

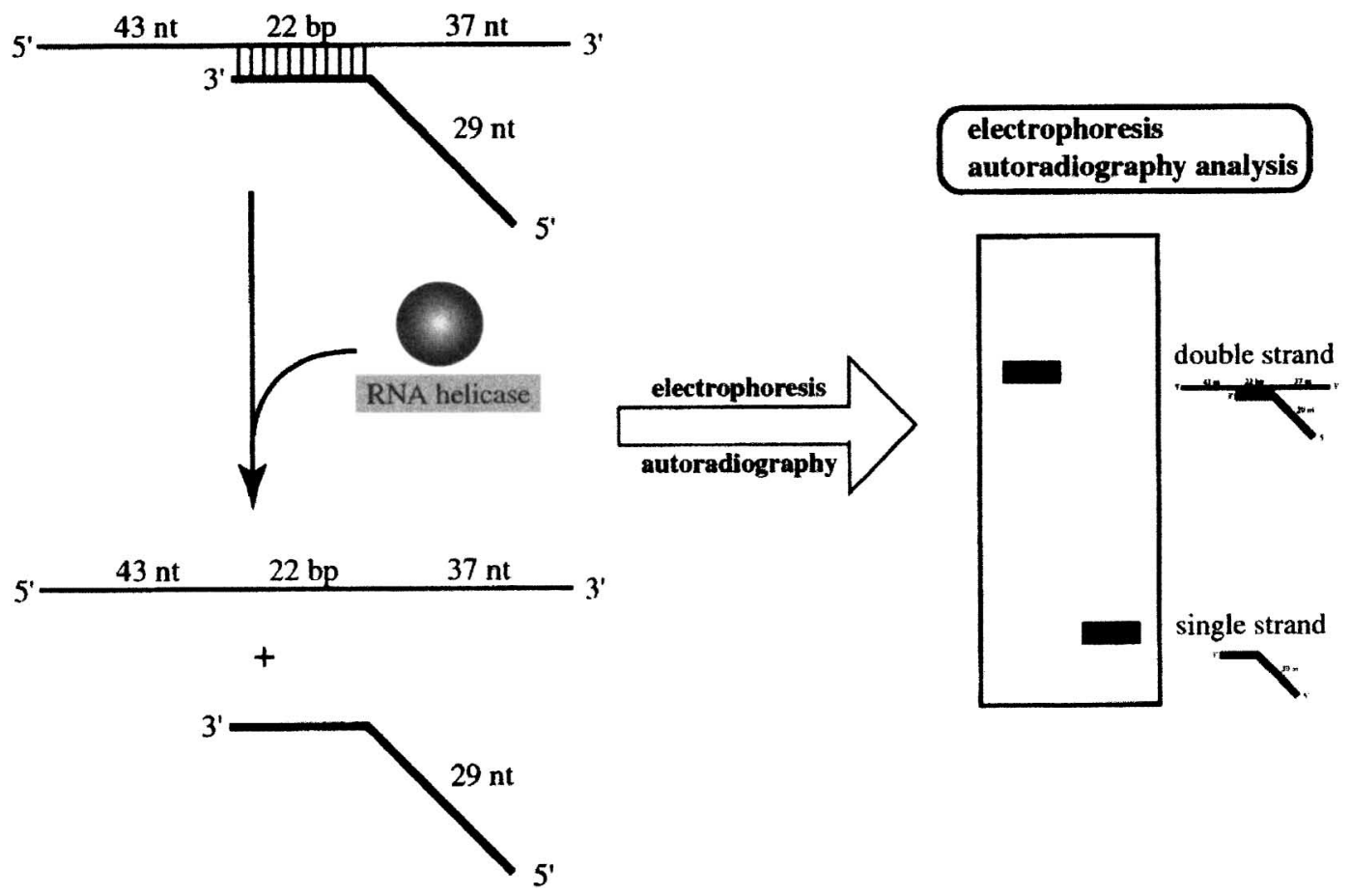

Fig. 2 System of RNA Helicase Assay. 


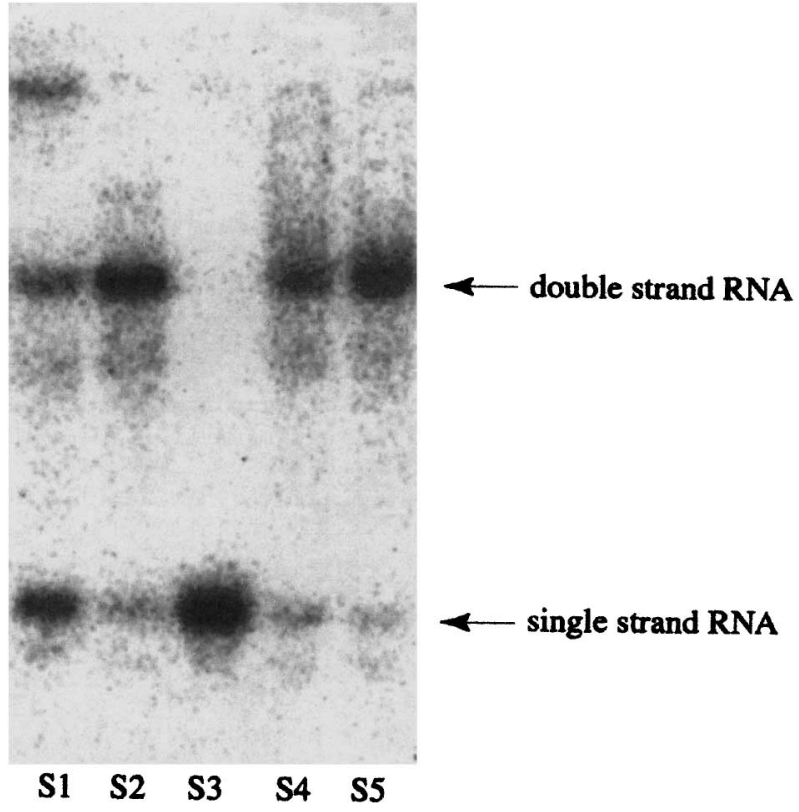

Fig. 3 RNA helicase activity of JEV NS3 and its inhibition by a substance from Streptomyces.

S1: positive control with JEV NS3; S2: negative control without JEV NS3; S3: boiled JEV NS3 substrate plus JEV NS3; S4: incubation with JEV NS3 and $0.05 \mu \mathrm{g}$ inhibitory substance; S5: incubation with JEV NS3 and $0.1 \mu \mathrm{g}$ inhibitry substance.

Thus, we demonstrated that a substance isolated from a strain of Streptomyces sp. effectively inhibited ATPase as well as RNA helicase activity of JEV. This is the first report on the natural inhibitor of ATPase and RNA helicase activity, although its inhibition mechanism remains to be clarified.

\section{References}

1) Kuno, G., Chaang, G.J.J., Tsuchiya, K.R., Karabatos, N., and Cropp, C.B.: Phylogeny of the genus Flavivirus. J. Virol. 72: 73-83, 1998.

2) Chambers, T.J., Weir, R.C., Grakoui, A., McCourt, D.W., Bazan, J.F., Fletterik, R.J., and Rice, C.M.: Evidence that $\mathrm{N}$-terminal domain of nonstructural protein NS3 from yellow fever virus is a serine protease responsible for site-specific cleavages in the viral polyprotein. Proc. Natl. Acad. Sci. USA 87: 8898-8902, 1990.

3) Preugschat, F., Lences, E.M., and Strauss, J.H.: Flavivirus enzyme-substrate interactions studies with proteinases: Identification of an intragenic locus important for substrate recognition. J. Virol. 65: 4749-4758, 1991.

4) Li, H., Clum, S., You, S., Ebner, K.E., and Padmanabhan, R.: The serine protease and RNA-stimulated nucleoside triphosphatase and RNA helicase functional domains of dengue virus type 2 NS3 converge within a region of 20 amino acids. J. Virol. 73: 3108-3116, 1999.
5) Koonin, E. V.: Similarities in RNA helicases. Nature 352: 290, 1991.

6) Gorbalenya, A. E. and Koonin, E. V.: Helicase: amino acid sequence comparisons and structure-function relationships. Curr. Opin. Struct. Biol. 3: 419-429, 1993.

7) Kadare, G. and Haenni, A. L.: Virus-encoded RNA helicase. J. Virol. 323: 2583-2590, 1997.

8) Utama, A., Shimizu, H., Hasabe, F., Morita, K., Igarashi, A., Shoji, I., Matsuura, Y., Hatsu, M., Takamizawa, K., Hagiwara, A., and Miyamura, T.: Role of the DexH motif of the Japanese encephalitis virus and hepatitis $\mathrm{C}$ virus NS3 proteins in the ATPase and RNA helicase activities. Virology 273: 316-324, 2000.

9) Utama, A., Shimizu, H., Morikawa, S., Hasabe, F., Morita, K., Igarashi, A., Hatsu, M., Takamizawa, K. and Miyamura, T.: Identification and characterization of the RNA helicase activity of Japanese encephalitis virus NS3 protein. FEBS Lett. 465: 74-78, 2000.

10) Wu, X.C., Lee, W., Tran, L., and Wong, S.L.: Engineering a Bacillus subtilis expression-secretion system with a strain deficient in six extracellular proteases. J. Bacteriol., 173: 4952-4958, 1991.

11) Kato, T., Yamagata, Y., Arai, T., and Ichishima, E.: Purification of a new extracellular 90-kDa serine proteinase with isoelectric point of 3.9 from Bacillus subtilis (natto) and elucidation of its distinct mode of action. Biosci. Biotechnol. Biochem. 56: 1166-1168, 1992.

12) Yamagata, Y., Abe, R., Fujita, Y., and Ichishima, E., Molecular cloning and nucleotide sequence of the 90k serine protease gene, hspK, from Bacillus subtilis (natto) No. 16. Curr. Microbiol. 31: 340-344, 1995.

13) Strongin, A.Y., Izotova, L.S., Abramov, Z.T., Ermakova, L.M., Gorodetsky, D.I. and Stepanov, V.M.: On the appearance of Bacillus subtilis intracellular serine protease in the cell membrane and culture medium. Comparison of the enzyme and other Bacillus subtilis serine proteases. Arch. Microbiol. 119: 287-293, 1978.

14) Roitsch, C.A., and Hageman, J.H., Bacillopeptidase F: Two forms of a glycoprotein serine protease from Bacillus subtilis 168. J. Bacteriol. 155: 145-152, 1983.

15) Rufo, G.A., Sullivan, B.J., Sloma, A., and Pero, J.: Isolation and characterization of a novel extracellular metalloprotease from Bacillus subtilis.: J. Bacteriol. 172: 1019-1023, 1990.

16) Sloma, A., Rufo, G.A., Rudolph, C.F., Sullivan, B.J., Theriault, K.A., and Pero, J., Bacillopeptidase F of Bacillus subtilis: Purification of the protein and cloning of the gene. J. Bacteriol. 172: 1470-1477, 1990.

17) Wu, X.C., Nathoo, S., Pang, A.S., Carne, T. and Wong, S.L.: Cloning, genetic organization, and characterization of a structural gene encoding bacillopeptidase $\mathrm{F}$ from Bacillus subtilis. J. Biol. Chem. 265: 6845-6850, 1990.

18) Gorbalenya, A. E., Koonin, E. V., Donchenko, A. P., and Blinov, V. M. Two related superfamilies of putative helicase involved in replication, recombination, repair and expression of DNA and RNA genomes. Nucleic Acids Res. 17: 4713-4736, 1989. 